\title{
Expression profile of parkin isoforms in human gliomas
}

\author{
GRAZIA MAUGERI $^{1}$, AGATA GRAZIA D'AMICO ${ }^{1}$, GAETANO MAGRO $^{2}$, LUCIA SALVATORELLI ${ }^{2}$, \\ GIUSEPPE M.V. BARBAGALLO ${ }^{3}$, SALVATORE SACCONE ${ }^{4}$, FILIPPO DRAGO ${ }^{5}$, \\ SEBASTIANO CAVALLARO $^{6}$ and VELIA D'AGATA ${ }^{1}$
}

\author{
${ }^{1}$ Department of Biomedical Sciences and Biotechnology, Section of Anatomy and Histology, University of Catania; \\ ${ }^{2}$ G.F. Ingrassia Department, Anatomic Pathology, University of Catania; ${ }^{3}$ Neurosurgery Department, \\ Policlinico ‘G. Rodolico' University Hospital; ${ }^{4}$ Department of Biological, Geological and Environmental Sciences, \\ Section of Animal Biology, University of Catania; ${ }^{5}$ Department of Biomedical Sciences and Biotechnology, \\ Section of Pharmacology and Biochemistry, University of Catania; ${ }^{6}$ Functional Genomics Center, \\ Institute of Neurological Sciences, Italian National Research Council, Catania, Italy
}

Received February 16, 2015; Accepted March 12, 2015

DOI: 10.3892/ijo.2015.3105

\begin{abstract}
Mutations of parkin gene are not restricted to familial forms of Parkinsonism but they also occur in a wide variety of malignancies including gliomas. Parkin overexpression reduces glioma cells proliferation and analysis of its expression is predictive for the survival outcome of patients with glioma. To date have been identified 21 parkin alternative splice variants. However, most of the studies have focused their attention exclusively on full-length protein. In the present study, the expression profile of parkin isoforms in different grades of astrocytomas was analyzed for the first time, in order to evaluate their involvement in this malignancy. Furthermore, to investigate their role in cellular processes, their expression in three glioblastoma cell lines was analyzed following treatment with the proteasome inhibitor MG132, or induction of mitophagy with CCCP, or after serum deprivation. Results suggested that $\mathrm{H} 20, \mathrm{H} 1$ and $\mathrm{H} 5$ isoforms are always expressed in tumors both in vivo and in vitro models. Therefore, these isoforms might be used as specific biomarkers to develop a prognostic tool for brain tumors.
\end{abstract}

\section{Introduction}

Parkin (PARK2) is one of the largest genes in human genome, located in the long arm of chromosome 6 (6q25.2-q27). The first isolated human parkin transcript was of 2,960 bases encoding a protein of 465 amino acids also known as full length

Correspondence to: Professor Velia D'Agata, Department of Biomedical Sciences and Biotechnology, Section of Anatomy and Histology, University of Catania, Via S. Sofia, 87, 95123 Catania, Italy E-mail: vdagata@unict.it

Key words: parkin isoforms, astrocytoma, glioblastoma cells, alternative splicing, mRNA Parkin variants parkin (GenBank: BAA25751.1) (1). To date, GenBank lists 26 human PARK2 transcripts corresponding to 21 different alternative splice variants. Each of these variants presents a different molecular architecture and domain composition. In a recent review, an update of all human PARK2 alternative splice transcripts and isoforms presently known is provided, and correlated to those in rat and mouse, two common animal models for studying human disease genes (2). The canonical parkin protein is characterized by multiple domains comprising an $\mathrm{N}$-terminal ubiquitin-like domain (Ubl), a cysteine-rich RING0 domain, and 2 C-terminal really interesting new gene (RING) domains (RING1 and RING2) separated by a cysteine-rich, zinc-binding in between RING (IBR) domain $(3,4)$. Parkin protein acts as an E3 ubiquitin ligase, catalyzing the covalent attachment of ubiquitin to lysine residues within substrate proteins (5). Parkin is widely distributed in a variety of tissues, predominantly in brain (6-8). To date wide neuroprotective activity in cellular and animal models has been described (9-11). The protein could mediate this effect by at least three mutually non-exclusive mechanisms including proteasomal degradation of toxic substrates, or removal of damaged mitochondria via mitophagy or its involvement in cell death (12-14).

Mutations of parkin gene were first described as causing juvenile Parkinsonism (AR-JP) (15) an autosomal recessive disorder characterized by classic clinical symptoms of idiopathic Parkinson's disease (PD) $(16,17)$. Although many studies have focused on the characterization of parkin function in neurodegeneration, in recent years, the role of this gene in cancer has gained more attention. It is now clear that its alterations are not restricted to familial forms of Parkinson disease but also occur in a wide variety of tumors, including gliomas (18-22). The most common and lethal primary malignancy of the central nervous system (CNS) is glioblastoma multiforme (GBM). It is classified as IV grade astrocytoma, and it can be either primary or secondary. Primary GBM occurs de novo, without evidence of a less malignant precursor, whereas secondary GBM develops from an initially low-grade diffuse (grade II) or anaplastic (grade III) astrocytoma (23). GBM typically has a very high 
proliferative rate with widespread microvascular proliferation and areas of focal necrosis $(24,25)$.

Genetic abnormalities in this tumor include also alteration of parkin gene. Notably, it has been observed that somatic parkin mutations in cancer occur in the same domains as the germline PD mutations. In both cases, mutations cluster in the ubiquitin-like domain (UBL), the RING finger domain and the in-between RING finger domain (IBR) (26). Furthermore, previous studies have shown that overexpression of parkin in glioma cells mitigates their proliferation and promotes reduction in cyclin D1 levels suggesting that its expression is inversely related to carcinogenicity. Parkin is also able to downregulate levels of VEGFR2, suggesting that it may have a role in suppression of cancer angiogenesis $(22,27)$. To date, studies mainly focused on the role of full-length parkin, ignoring the existence of other isoforms.

Alternative splicing of coding exons may generate protein isoforms with different biological properties, protein-protein interactions, subcellular localization, signaling pathway or catalytic ability $(28,29)$. This process, therefore, represents an extremely economical mean of increasing protein diversity, which can finely tune genomic information to meet the unique needs of each cell (30). Alternative splicing produces different parkin variants with different expression patterns in tissues and cells (31-33). These transcripts might carry out different or even opposing biological functions (34-36).

In light of the evidence described above, in the present study we analyzed, for the first time, the expression profile of parkin isoforms in different grades of astrocytomas, in order to evaluate their involvement in tumor malignancy. In addition, we analyzed some of their functions in three glioblastoma cell lines. In particular, we studied their involvement in protein degradation or in mitophagy or in apoptotic cellular death. This study demonstrated that expression of some parkin isoforms is related to astrocytoma malignancy. The in vitro study also showed that the expression profile of the isoforms and their functions change in relation to cellular phenotype. In conclusion, a deeper characterization of such isoforms might be useful to develop a prognostic tool of some brain tumors.

\section{Materials and methods}

Human brain samples and cell lines. The study was performed on formalin-fixed tissue sections of different grade [II, III, IV according to World Health Organization (WHO) criteria] human astrocytomas or on frozen section of a glioblastoma of anonymous patients provided by G.F Ingrassia Department of Anatomic Pathology. Experiments were also carried on human glioblastoma cells T98G (ATCCC number CRL-1690), A172 (ATCCC number CRL-1620) and U87-MG (ATCCC number HTB-14). Cells were cultured in Dulbecco's modified Eagle's medium (DMEM) supplemented with $10 \%$ of heat-inactivated fetal bovine serum (FBS), $100 \mathrm{U} / \mathrm{ml}$ penicillin, and $100-\mu \mathrm{g} / \mathrm{ml}$ streptomycin (Lonza, Milan, Italy) and they were incubated at $37^{\circ} \mathrm{C}$ in a humidified atmosphere with $5 \% \mathrm{CO}_{2}$. Once cells reached confluence, they were cultured for $24 \mathrm{~h}$ in complete medium containing 10\% FBS (control) or in 10\% FBS added with $10 \mu \mathrm{M}$ MG132, a proteasome inhibitor, or in $10 \% \mathrm{FBS}$ added with $10 \mu \mathrm{M}$ carbonyl cyanide 3-chlorophenylhydrazone
(CCCP), a mitochondrial uncoupling agent that dissipates the membranes, or in total absence of serum (SS).

FFPE tissue samples. Formalin-fixed, paraffn-embedded $15-\mu \mathrm{m}$ thick tissue sections from anonymous patients affected by astrocytoma (4 with grade II, 5 with grade III, and 5 with grade IV) were collected in tubes. Protein extraction was accomplished with Qproteome FFPE Tissue Extraction Buffer (Qiagen) as specified in the instruction manual. Briefly, tissue sections were deparaffinized with xylene (Sigma-Aldrich, St. Louis, MO, USA) and rehydrated with a graded ethanol series (100, 96 and 70\%). Extraction buffer, containing $\beta$-mercaptoethanol, was added to pellet of each tube and incubated at $100^{\circ} \mathrm{C}$ for $20 \mathrm{~min}$, followed by an incubation at $80^{\circ} \mathrm{C}$ for $2 \mathrm{~h}$. Finally, the tubes were centrifuged for $15 \mathrm{~min}$ at $14000 \mathrm{x}$ g. The supernatant containing the extracted proteins was collected and stored at $4^{\circ} \mathrm{C}$. Protein concentration was determined with a fluorescence microplate reader by using the Quant-iT Protein Assay kit (Invitrogen, Carlsbad, CA, USA).

Immunoprecipitation protocol. Immunoprecipitation was performed by using Dynabeads Protein A Immunoprecipitation Kit as specified in the instruction manual (Life Technologies). Briefly, $1 \mu \mathrm{g}$ of rabbit anti-Park 2 polyclonal antibody (cat. no. PAB1105, Abnova; abbreviated as AbI) or $1 \mu \mathrm{g}$ of rabbit anti-Parkin (cat. no. AB5112, Millipore; abbreviated as AbII) conjugated with dynabeads were prepared and stored in PBS with $0.1 \%$ Tween-20. At the time of use, the tubes containing dynabeads AbI or AbII complex were placed on a magnet and supernatant was removed. Then, $400 \mu \mathrm{g}$ of homogenate cell lysate was added to each tube to allow antigen $(\mathrm{Ag})$ to bind to the antibody. The tubes containing dynabeads Ab-Ag complex was placed on a magnet and supernatant was removed. The complex was resuspended in $20 \mu \mathrm{l}$ elution buffer with $2 \mathrm{X}$ Laemmli buffer and processed for western blot analysis.

Western blot analysis. Western blot analysis was performed to determine the relative levels of parkin isoform protein. Proteins were extracted with buffer containing $20 \mathrm{mM}$ Tris (pH 7.4), 2 mM EDTA, 0.5 mM EGTA; 50 mM mercaptoethanol, $0.32 \mathrm{mM}$ sucrose and a protease inhibitor cocktail (Roche Diagnostics) using a Teflon-glass homogenizer and then sonicated twice for $20 \mathrm{sec}$ using an ultrasonic probe, followed by centrifugation at $10000 \mathrm{x}$ g for $10 \mathrm{~min}$ at $4^{\circ} \mathrm{C}$. Protein concentrations were determined by the Quant-iT Protein Assay kit (Invitrogen). Proteins $(\sim 100 \mu \mathrm{g})$ from formalin-fixed tissue sections or $65 \mu \mathrm{g}$ from fresh frozen section per sample were diluted in $2 \mathrm{X}$ Laemmli buffer (Invitrogen), heated at $70^{\circ} \mathrm{C}$ for $10 \mathrm{~min}$ and then separated on a Bio-Rad Criterion XT 4-15\% Bis-tris gel (Invitrogen) by electrophoresis and then transferred to a nitrocellulose membrane (Invitrogen). Blots were blocked using the Odyssey Blocking Buffer (LI-COR Biosciences, Lincoln, NE, USA). The transfer was monitored by a prestained protein molecular weight marker (Bio-Rad Laboratories, Hercules, CA, USA). Immunoblot analysis was performed by using appropriate antibodies: AbI (1:500), AbII (1:1000) and rabbit anti- $\beta$-tubulin (cat. no. sc-9104, Santa Cruz Biotechnology, Santa Cruz, CA, USA; 1:500). The secondary antibody goat anti-rabbit IRDye $800 \mathrm{CW}$, (cat. \#926-32211; LI-COR Biosciences), was used at 1:20000. 
Blots were scanned with Odissey Infrared Imaging System (Odyssey). Densitometric analyses of western blot signals were performed at non-saturating exposures and analyzed using ImageJ software (NIH, Bethesda, MD, USA; available at http://rsb.info.nih.gov/ij/index.html). Values were normalized to $\beta$-tubulin, which served as loading control. No signal was detected when the primary antibody was omitted (data not shown).

Immunohistochemical analysis. Fresh-frozen sections of surgically resected tumor included in OCT were cutted and fixed in $4 \%$ paraformaldehyde for $30 \mathrm{~min}$ and then were treated with $3 \% \mathrm{H}_{2} \mathrm{O}_{2}$ in methanol for $10 \mathrm{~min}$ to inhibit the endogenous peroxidase activity. To reduce non-specific staining, sections were treated with $1 \%$ bovine serum albumin (BSA) in PBS for $1 \mathrm{~h}$, and incubated overnight at $4^{\circ} \mathrm{C}$ with appropriate antibody. The sections were rinsed in PBS and incubated with diaminobenzidine (DAB) for $5 \mathrm{~min}$. Hematoxylin was used as the nuclear counterstain. The stained sections were dehydrated through graded alcohols, cleared in xylene, and covered with neutral balsam.

Immunolocalization. T98G, A172 and U87MG cells line cultured on glass cover slips were fixed in $4 \%$ paraformaldehyde in PBS (15 min at room temperature), permeabilized with $0.2 \%$ Triton X100, blocked with $0.1 \%$ BSA in PBS, and then probed with appropriate primary antibodies as described above. AbI (1:100), AbII (1:1000) and mouse anti- $\beta$-actin (1:700) (cat. no. \#MAB1501R Millipore) primary antibodies were detected with Alexa Fluor 488 goat anti-rabbit and Alexa Fluor 594 goat anti-mouse, respectively, for $1.5 \mathrm{~h}$ at room temperature and shielded from light. DNA was counterstained with DAPI (\#940110, Vector Laboratories Inc., Burlingame, CA, USA). After a series of PBS and double-distilled water washes, the fixed cells were cover-slipped with Vectashield mounting medium (Vector Laboratories, Inc.). Localization of two parkin antibodies and $\beta$-actin was then performed by confocal laser scanning microscopy (CLSM; Zeiss LSM700).

Statistical analysis. Data are reported as mean \pm SEM. One-way analysis of variance (ANOVA) was used to compare differences among groups, and statistical significance was assessed by the Tukey-Kramer post hoc test. The level of significance for all statistical tests was $\mathrm{p} \leq 0.05$.

\section{Results}

Differential expression of parkin isoforms in gliomas. In a previous study, a diversified panel of antibodies recognizing different domain of the originally cloned Parkin (GenBank: BAA25751.1) was described (31). Two of them were selected for the present study, AbI and AbII. As displayed in Table I, when the amino acid sequence recognized by each antibody perfectly (more than 8 amino acids) match with the sequence of the protein, it is very likely to get a signal by western blot or immunohistochemistry analysis (this is indicated in the table by 'Yes'). If the antibody recognizes at least 8 consecutive amino acids on the protein, it is likely to visualize a signal by western blot or immunohistochemistry analysis (this is indicated in the table by 'Maybe'). Whereas, if the antibody
Table I. Parkin isoforms recognized by antibody AbI and AbII.

\begin{tabular}{lccc}
\hline Code identifier & Predicted MW & AbI & AbII \\
\hline H20 & 58.127 & Yes & Yes \\
H1 & 51.65 & Yes & Yes \\
H5 & 48.713 & Yes & Yes \\
H10 & 46.412 & Yes & No \\
H14 & 43.485 & Yes & No \\
H4 & 42.407 & Yes & Yes \\
H8 & 42.52 & No & Yes \\
H17 & 42.52 & No & Yes \\
H21 & 39.592 & No & Yes \\
H6 & 35.63 & No & Yes \\
H11 & 30.615 & No & Yes \\
H2 & 30.155 & No & Yes \\
H3 & 22.192 & No & Yes \\
H12 & 19.201 & No & Maybe \\
H9 & 15.521 & Yes & No \\
H13 & 15.521 & Yes & No \\
H7 & 15.407 & No & No \\
H18 & 15.393 & No & No \\
H15 & 10.531 & No & No \\
H19 & 6.832 & No & No \\
H16 & 5.348 & No & No \\
\hline
\end{tabular}

Yes: perfect match between predicted protein sequence and antibody epitope. No: matching between predicted protein sequence and antibody epitope is less than 8 consecutive amino acids. Maybe: partial match between predicted protein sequence and antibody epitope.

recognizes less than 8 consecutive amino acids, it could rule out the possibility to visualize a signal on immunoblot or by immunohistochemistry analysis (this is indicated in the table by 'No').

In order to identify the expression pattern of parkin isoforms in gliomas, western blot analysis on tissue homogenates was performed from deparaffinized sections of different grade (II, III, IV) astrocytomas. These data were compared with the result obtained in tissue homogenate from frozen sample of a glioblastoma multiforme. As shown in Fig. 1, in all tumor samples bands of $\sim 58$ and $\sim 50 \mathrm{kDa}$ molecular weight, both with $\mathrm{AbI}$ and AbII antibody were detected, corresponding to $\mathrm{H} 20, \mathrm{H} 1$ and $\mathrm{H} 5$ isoforms, respectively. Furthermore, as predicted in Table I, a band of $\sim 15 \mathrm{kDa}$, corresponding to $\mathrm{H} 9, \mathrm{H} 13, \mathrm{H} 7$ and $\mathrm{H} 18$ isoforms, was only observed by using AbI antibody. Furthermore, in a frozen sample of glioblastoma, a further band of $\sim 42 \mathrm{kDa}$ molecular weight corresponding to $\mathrm{H} 4$ isoform, was also visualized on the immunoblot by both antibodies (Fig. 1C-G). However, this signal could also correspond to $\mathrm{H} 8$ or $\mathrm{H} 17$ isoforms, detected only by AbII antibody. Unpredicted bands were observed on immunoblots from homogenates of both deparaffinized and frozen sections which could represent aspecific signals or isoforms not identified yet. The results from densitometric analysis of bands on the immunoblot showed that parkin 
A

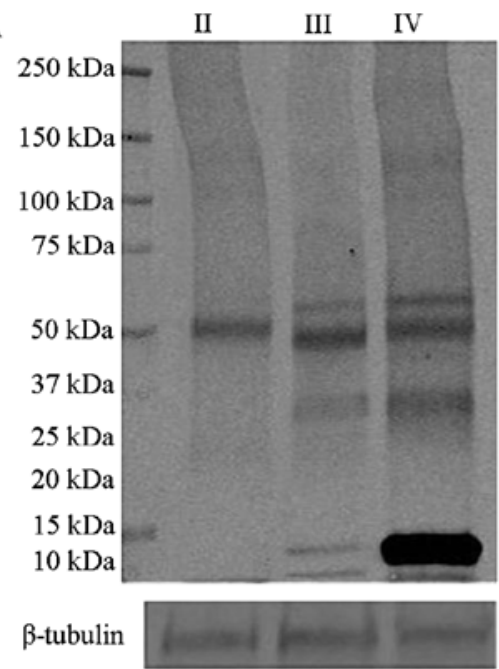

B

\begin{tabular}{|c|c|c|c|c|}
\hline $\begin{array}{c}\text { AbI } \\
\text { ID }\end{array}$ & MW & $\begin{array}{c}\text { II } \\
\text { Mean } \pm \text { SEM }\end{array}$ & $\begin{array}{c}\text { III } \\
\text { Mean } \pm \text { SEM }\end{array}$ & $\begin{array}{c}\text { IV } \\
\text { Mean } \pm \text { SEM }\end{array}$ \\
\hline H20 & $58 \mathrm{kDa}$ & $0.17 \pm 0.06$ & $0.55 \pm 0.10^{* *}$ & $0.87 \pm 0.10^{* * * \hbar}$ \\
\hline H1/HS & $50 \mathrm{kDa}$ & $1.71 \pm 0.13$ & $1.59 \pm 0.19$ & $1.73 \pm 0.07$ \\
\hline H9/H13/H7/H18 & $15 \mathrm{kDa}$ & $0.95 \pm 0.11$ & $4.86 \pm 0.03^{* * *}$ & $8.83 \pm 0.09 * * *$ *⿻丷木 \\
\hline
\end{tabular}

$\mathbf{E}$

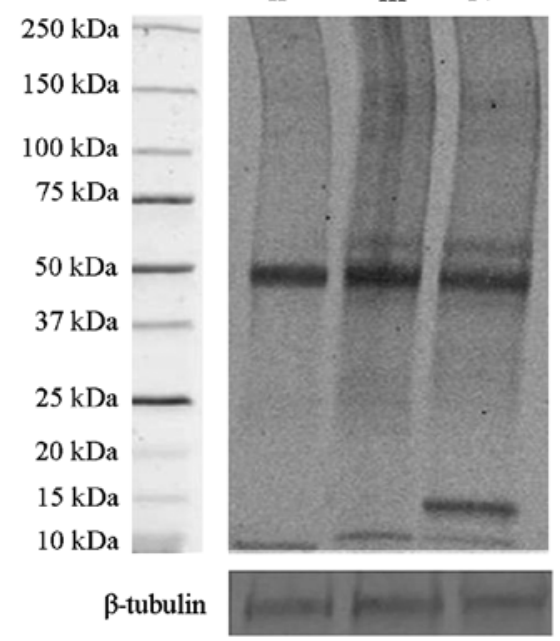

$\mathbf{F}$

\begin{tabular}{|c|c|c|c|c|}
\hline $\begin{array}{c}\text { AbI } \\
\text { ID }\end{array}$ & MW & $\begin{array}{c}\text { II } \\
\text { Mean } \pm \text { SEM }\end{array}$ & $\begin{array}{c}\text { III } \\
\text { Mean } \pm \text { SEM }\end{array}$ & $\begin{array}{c}\text { IV } \\
\text { Mean } \pm \text { SEM }\end{array}$ \\
\hline H20 & $58 \mathrm{kDa}$ & $0.13 \pm 0.08$ & $0.31 \pm 0.08 *$ & $0.60 \pm 0.05 * * * A s$ \\
\hline $\mathrm{H} 1 / \mathrm{HS}$ & $50 \mathrm{kDa}$ & $1.67 \pm 0.09$ & $1.87 \pm 0.43$ & $1.64 \pm 0.10$ \\
\hline
\end{tabular}

C

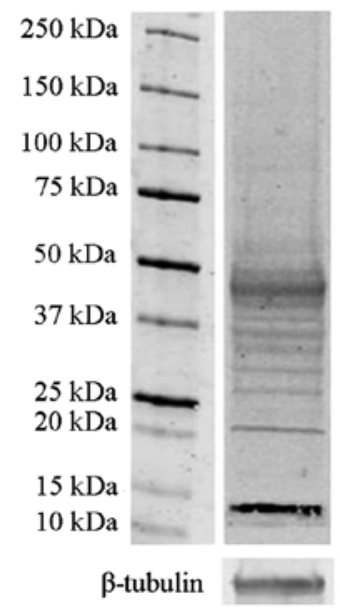

D

\begin{tabular}{|c|c|c|}
\hline $\begin{array}{c}\text { AbI } \\
\text { ID }\end{array}$ & MW & $\begin{array}{c}\text { IV } \\
\text { Mean } \pm \text { SEM }\end{array}$ \\
\hline $\mathrm{H} 20$ & $58 \mathrm{kDa}$ & $0.11 \pm 0.01$ \\
\hline $\mathrm{H} 1 / \mathrm{HS}$ & $50 \mathrm{kDa}$ & $0.81 \pm 0.10$ \\
\hline $\mathrm{H} 14 / \mathrm{H} 4$ & $42 \mathrm{kDa}$ & $0.13 \pm 0.01$ \\
\hline $\mathrm{H} 9 / \mathrm{H} 13 / \mathrm{H} 7 / \mathrm{H} 18$ & $15 \mathrm{kDa}$ & $1.07 \pm 0.05$ \\
\hline
\end{tabular}

G

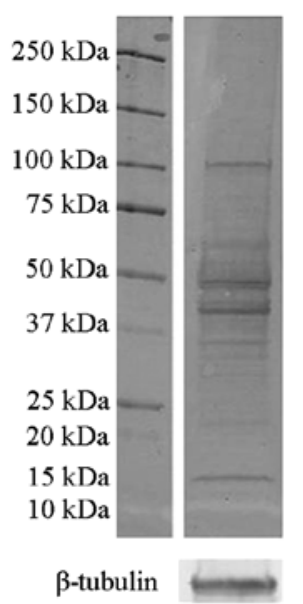

H

\begin{tabular}{|c|c|c|}
\hline $\begin{array}{c}\text { AbI } \\
\text { ID }\end{array}$ & MW & $\begin{array}{c}\text { IV } \\
\text { Mean } \pm \text { SEM }\end{array}$ \\
\hline H20 & $58 \mathrm{kDa}$ & $0.13 \pm 0.02$ \\
\hline $\mathrm{H} 1 / \mathrm{H} 5$ & $50 \mathrm{kDa}$ & $0.31 \pm 0.02$ \\
\hline $\mathrm{H} 14 / \mathrm{H} 4$ & $42 \mathrm{kDa}$ & $0.32 \pm 0.03$ \\
\hline
\end{tabular}

Figure 1. Expression pattern of parkin isoforms in astrocytomas of different grade. Representative immunoblots of signals detected by Ab I (A and C) and $\mathrm{AbII}$ (E and G) on tissue homogenates of from deparaffinized sections of different grade (II, III, IV) human astrocytomas (A and E) or from frozen section of glioblastoma (C and G). The tables (B, D, F and H) show data of densitometric analysis of each immunoblot expressed as mean \pm SEM. Values were normalized to relative $\beta$-tubulin signal. ${ }^{*} \mathrm{p}<0,05$ vs. Astrocytoma $2^{\circ} ;{ }^{* *} \mathrm{p}<0.01$ vs. Astrocytoma $2^{\circ} ;{ }^{* * *} \mathrm{p}<0.001$ vs. Astrocytoma $2^{\circ} ;{ }^{\#} \mathrm{p}<0.05$ vs. Astrocytomas $3^{\circ} ;{ }^{\# \#} \mathrm{p}<0.01$ vs. Astrocytomas $3^{\circ} ;{ }^{\# \#} \mathrm{p}<0.01$ vs. Astrocytomas 3 ; as determined by one-way ANOVA followed by the Tukey post hoc test.

expression is higher in malignant glioblastomas than in less invasive gliomas (Fig. 1A, B, E and F). In particular expression levels of $\mathrm{H} 20$ and $\mathrm{H} 9 / \mathrm{H} 13 / \mathrm{H} 7 / \mathrm{H} 18$ isoforms were significantly increased in astrocytomas of grade IV and III as compared to grade II, while the expression levels of isoforms $\mathrm{H} 1$ and $\mathrm{H} 5$ remain similar in all analyzed astrocytomas.
Tissue distribution of parkin isoforms in glioblastoma. To determine tissue distribution of parkin isoforms, immunohistochemical analyses were carried out in frozen sections of a human glioblastoma sample from an anonymous patient, used also for western blot analysis. Although anti-parkin antibodies are not able to discriminate among the various isoforms, a 


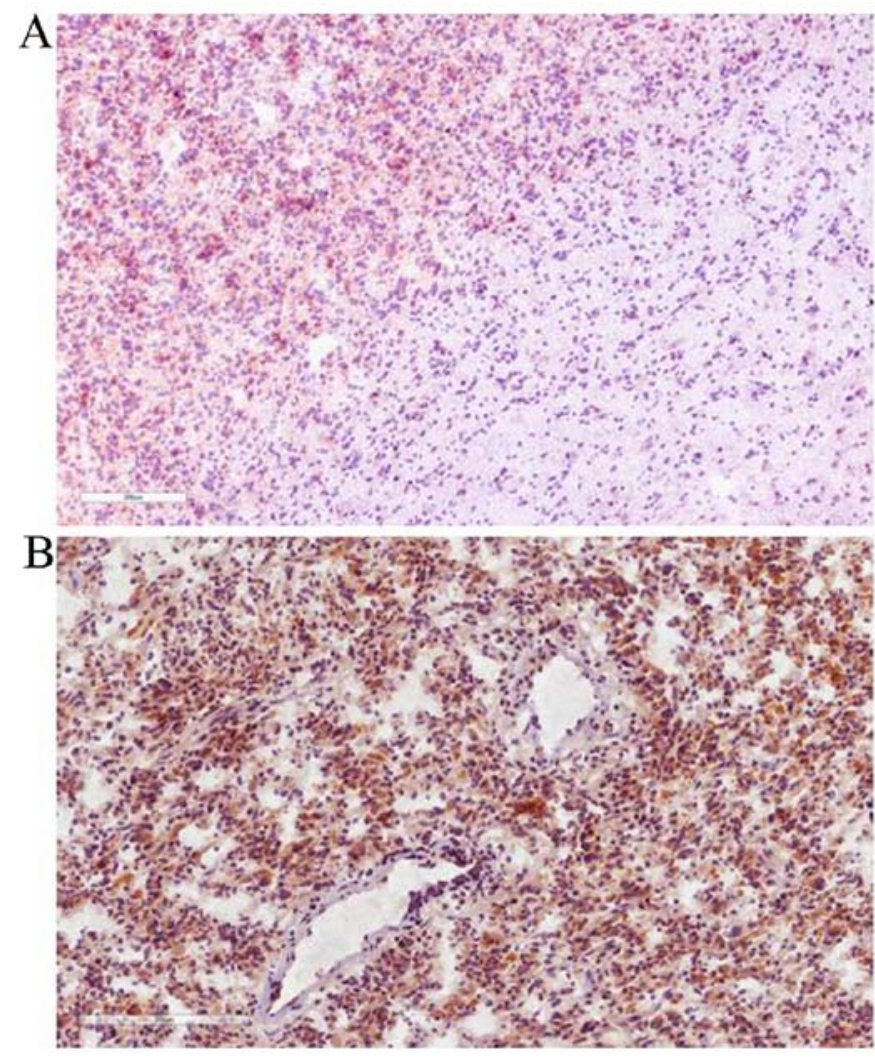

Figure 2. Immunostaining of parkin in frozen sections of glioblastoma Representative photomicrographs showing cytoplasmic immunoreactivity obtained with AbI (A) and AbII (B). Alternating positive- and negative-tumor areas (A) or only positive-tumor area (B) are seen (original magnification for both $\mathrm{A}$ and $\mathrm{B}$ : x100; immunoperoxidase technique).

heterogeneous distribution of the protein in this tumor was observed. Regardless of the AbI or AbII antibody used, parkin immunoreactivity was obtained in the cytoplasm of neoplastic cells (Fig. 2A and B). Endothelial cells of tumoral blood vessels did not stain (Fig. 2B).

Expression profile of parkin isoforms in glioblastoma cell lines. To characterize the isoform function, we analyzed their expression profile in three glioblastoma cell lines. As shown in Figs. 3 and 4, cells expressed different levels of H20, H1 and $\mathrm{H} 5$ isoforms, corresponding to bands of molecular weight $\sim 58$ and $\sim 50 \mathrm{kDa}$, respectively. Furthermore, as predicted in Table I, a faint band of $20 \mathrm{kDa}$, corresponding to $\mathrm{H} 3$ and $\mathrm{H} 12$ isoforms, was also observed in the blot by using AbII antibody, however, we did not performed densitometric analysis of the signal since it was extremely low (Fig. 4A-C).

We investigated the role of isoforms in some experimental conditions previously used to test full lenght parkin function (37-40). Cells were cultivated for $24 \mathrm{~h}$ in $10 \% \mathrm{FBS}$

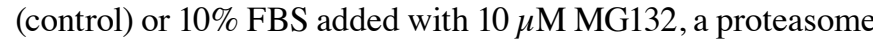
inhibitor, or $10 \%$ FBS added with $10 \mu \mathrm{M}$ carbonyl cyanide 3-chlorophenylhydrazone (CCCP), a mitochondrial uncoupling agent that dissipates the membranes, or in total absence of serum (SS) to evaluate isoform expression during cell death. In the cells, the expression of $\mathrm{H} 1$ and $\mathrm{H} 5$ isoforms was significantly increased following proteasome inhibition as compared to control. In the same experimental conditions, the expression of $\mathrm{H} 20$ isoform was unchanged when compared to control. Whereas, expression levels of H1, H5 and H20 isoforms were significantly increased after CCCP treatment only in T98G and U87MG cells compared to their controls. Finally, serum deprivation increased the expression of $\mathrm{H} 1$ and $\mathrm{H} 5$ isoforms in T98G and A172 cells, whereas the expression of H20 isoform was significantly increased only in T98G cells.

Immunolocalization of parkin isoforms in glioblastoma cell lines. To investigate parkin isoform distribution, we detected their expression in cells grown in complete medium containing $10 \%$ FBS, or in $10 \%$ FBS added with $10 \mu \mathrm{M} \mathrm{MG132}$, or in $10 \%$ FBS added with $10 \mu \mathrm{M}$ carbonyl cyanide 3-chlorophenylhydrazone (CCCP), or in total absence of serum (SS) for $24 \mathrm{~h}$ by using immunofluorescent analysis.

The analysis does not allow discrimination among isoforms, therefore, we calculated their total expression in each experimental condition by summing mean values obtained by western blot analysis (the tables in Figs. 3 and 4). The results reported in the tables (in Figs. 5 and 6) confirm a correlation of data obtained through both techniques. Expression of total isoforms in T98G cells increases after treatments and particularly after serum deprivation (Figs. 5a and 6a). In all experimental conditions parkin was observed in the cytoplasm (Figs. 5A and 6A). In cells treated with MG132, immunoreactivity is observed also at nuclear and perinuclear level (Figs. 5A and 6A). In early studies, parkin was described in the nucleus (41-46). According to data reported in Table b and e (Figs. 5 and 6, respectively), in A172 cells, total expression of isoforms appears to be unchanged in all experimental conditions considered. They seemed predominantly localized in the cytoplasm (Figs. 5B and 6B). Finally, according to data obtained (Figs. 5c and $6 \mathrm{c}$, respectively) total expression of parkin isoforms in U87MG cells seemed increased after treatment with MG132 or after induction of mitophagy with CCCP. In both these experimental conditions, parkin immunoreactivity was also observed at the nuclear level.

\section{Discussion}

In this study, parkin isoform expression pattern in human gliomas was investigated, for the first time. Previous papers have already described somatic mutations of PARK2 gene in glioblastoma (26) and, more generally, its involvement in cancer (27), but focusing solely on the full-length isoform. To date, at least 21 isoforms have been identified in humans (31), but for most of them their functions have not yet been characterized. Based on the predicted amino acid sequence, it has been suggested that there are no commercially available antibodies that allow discrimination between these isoforms by using the most common methods of analysis (31).

Recently, 32 antibodies recognizing differently parkin isoforms were described (31). In our study we selected two of these antibodies, which, as described in Table I, identify some variants by using western blot analysis. In paraffinembedded tissues, it has been observed that the expression levels of the H20 isoform are increased with tumor malignancy. These results matched with those observed in a frozen tissue. However, in this latter case, a further band of $\sim 42 \mathrm{kDa}$ 
A

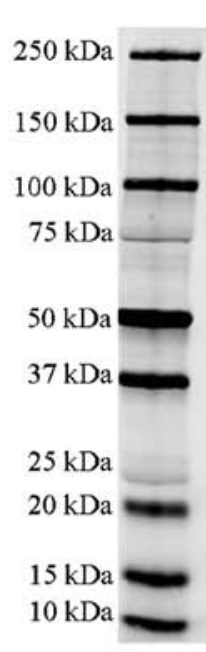

$\beta$-tubulin

\section{B}

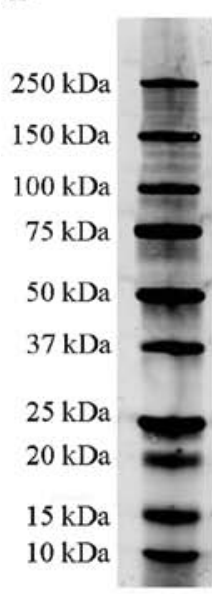

$\beta$-tubulin

C

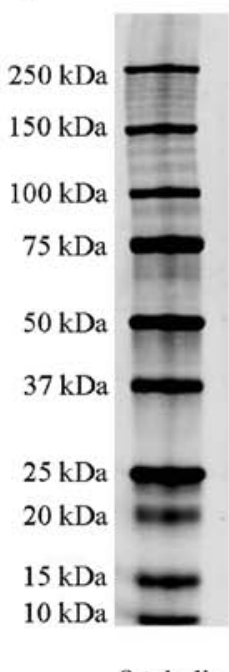

$10 \%$ FBS $10 \%$ FBS $10 \%$ FBS + MG132 +CCCP SS

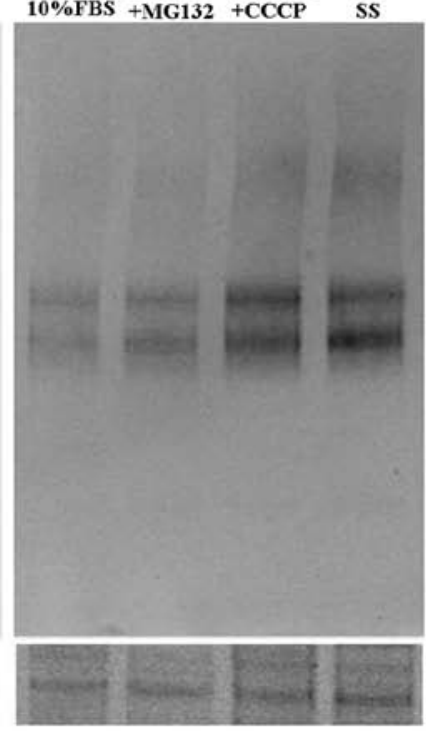

$10 \%$ FBS $10 \%$ FBS $10 \%$ FBS +MG132 +CCCP SS

\begin{tabular}{|c|c|c|c|c|c|}
\hline $\begin{array}{c}\text { AbI } \\
\text { ID }\end{array}$ & MW & $\begin{array}{c}10 \% \text { FBS } \\
\text { Mean } \pm \text { SEM }\end{array}$ & $\begin{array}{c}10 \% \text { FBS }+ \text { MG132 } \\
\text { Mean } \pm \text { SEM }\end{array}$ & $\begin{array}{c}10 \% \text { FBS+CCCP } \\
\text { Mean } \pm \text { SEM }\end{array}$ & $\begin{array}{c}\text { SS } \\
\text { Mean } \pm \text { SEM }\end{array}$ \\
\hline H20 & $58 \mathrm{kDa}$ & $0.54 \pm 0.07$ & $0.94 \pm 0.07$ & $2.00 \pm 0.18 * * *$ & $1.80 \pm 0.08 * * *$ \\
\hline H1/HS & $50 \mathrm{kDa}$ & $0.45 \pm 0.05$ & $1.16 \pm 0.08 * *$ & $1.48 \pm 0.05 * * *$ & $2.39 \pm 0.15 * * *$ \\
\hline
\end{tabular}

\begin{tabular}{|c|c|c|c|c|c|}
\hline $\begin{array}{c}\text { AbI } \\
\text { ID }\end{array}$ & MW & $\begin{array}{c}10 \% \text { FBS } \\
\text { Mean } \pm \text { SEM }\end{array}$ & $\begin{array}{c}10 \% \text { FBS+MG132 } \\
\text { Mean } \pm \text { SEM }\end{array}$ & $\begin{array}{c}10 \% \text { FBS+CCCP } \\
\text { Mean } \pm \text { SEM }\end{array}$ & $\begin{array}{c}\text { SS } \\
\text { Mean } \pm \text { SEM }\end{array}$ \\
\hline H20 & $58 \mathrm{kDa}$ & $0.26 \pm 0.05$ & $0.32 \pm 0.01$ & $0.30 \pm 0.01$ & $0.31 \pm 0.01$ \\
\hline H1/HS & $50 \mathrm{kDa}$ & $0.83 \pm 0.03$ & $1.16 \pm 0.08 *$ & $0.88 \pm 0.02$ & $1.10 \pm 0.06 *$ \\
\hline
\end{tabular}

$\beta$-tubulin

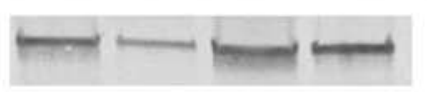

$10 \%$ FBS $\quad 10 \%$ FBS

$10 \%$ FBS + MG132 +CCCP SS

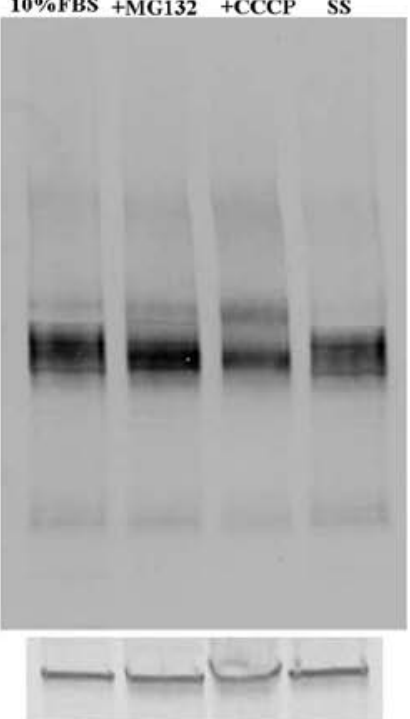

Figure 3. Expression profile of parkin isoforms in glioblastoma cell lines detected by the AbI antibody. Representative immunoblot of lysate from T98G (A), A172 (B) and U87MG (C) cells immunoprecipitated with AbI antibody. Cells were cultured in 10\% FBS or 10\% FBS with MG132 or 10\% FBS with CCCP or without serum (SS). Relative density of each band was quantified using ImageJ software. Each signal was normalized on correspondent $\beta$-tubulin signal. Data are expressed as mean \pm SEM. ${ }^{*}$ p $<0.05$ vs. $10 \%$ FBS, ${ }^{* *}$ p $<0.01$ vs. $10 \%$ FBS, ${ }^{* * *}$ p $<0.001$ vs. $10 \%$ FBS as determined by one-way ANOVA followed by the Tukey post hoc test. 
A

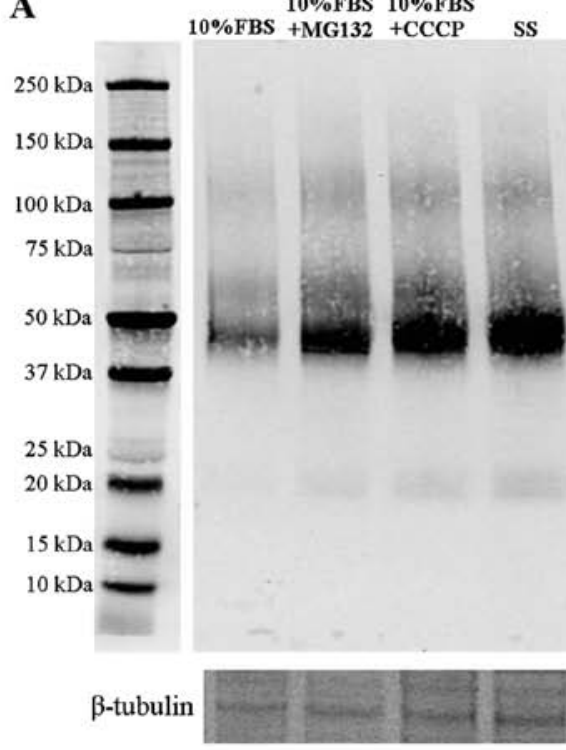

B

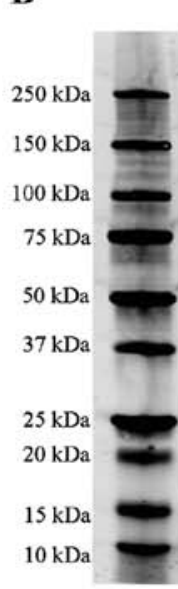

$\beta$-tubulin

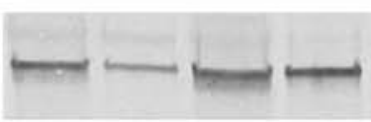

C

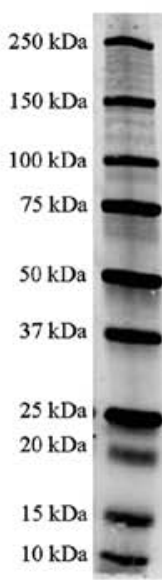

$\beta$-tubulin

$10 \%$ FBS $\begin{array}{ll}10 \% \text { FBS } & 10 \% \text { FBS } \\ + \text { MG132 } & + \text { CCCP }\end{array}$ SS

\begin{tabular}{|c|c|c|c|c|c|}
\hline $\begin{array}{c}\text { AbI } \\
\text { ID }\end{array}$ & MW & $\begin{array}{c}10 \% \text { FBS } \\
\text { Mean } \pm \text { SEM }\end{array}$ & $\begin{array}{c}10 \% \text { FBS }+ \text { MG132 } \\
\text { Mean } \pm \text { SEM }\end{array}$ & $\begin{array}{c}10 \% \text { FBS }+ \text { CCCP } \\
\text { Mean } \pm \text { SEM }\end{array}$ & $\begin{array}{c}\text { SS } \\
\text { Mean } \pm \text { SEM }\end{array}$ \\
\hline H20 & $58 \mathrm{kDa}$ & $0.15 \pm 0.01$ & $0.29 \pm 0.05$ & $0.35 \pm 0.03 *$ & $0.30 \pm 0.04 *$ \\
\hline HI/HS & $50 \mathrm{kDa}$ & $4.18 \pm 0.77$ & $1299 \pm 0.41 * * *$ & $13.25 \pm 0.92 * * *$ & $15.60 \pm 0.24 * * *$ \\
\hline
\end{tabular}

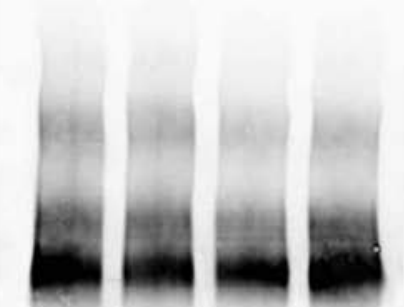

\begin{tabular}{|c|c|c|c|c|c|}
\hline $\begin{array}{c}\text { AbI } \\
\text { ID }\end{array}$ & MW & $\begin{array}{c}10 \% \text { FBS } \\
\text { Mean } \pm \text { SEM }\end{array}$ & $\begin{array}{c}10 \% \text { FBS }+ \text { MGG } 132 \\
\text { Mean } \pm \text { SEM }\end{array}$ & $\begin{array}{c}10 \% \text { FBS }+ \text { CCCP } \\
\text { Mean } \pm \text { SEM }\end{array}$ & $\begin{array}{c}\text { SS } \\
\text { Mean } \pm \text { SEM }\end{array}$ \\
\hline H20 & $58 \mathrm{kDa}$ & $0.40 \pm 0.06$ & $0.42 \pm 0.01$ & $0.31 \pm 0.02$ & $0.36 \pm 0.02$ \\
\hline H1/HS & $50 \mathrm{kDa}$ & $3.27 \pm 0.07$ & $3.89 \pm 0.10 * *$ & $3.44 \pm 0.13$ & $4.24 \pm 0.06 * * *$ \\
\hline
\end{tabular}

\begin{tabular}{|c|c|c|c|c|c|}
\hline $\begin{array}{c}\text { AbI } \\
\text { ID }\end{array}$ & MW & $\begin{array}{c}10 \% \text { FBS } \\
\text { Mean } \pm \text { SEM }\end{array}$ & $\begin{array}{c}10 \% \text { FBS } \\
\text { Mean } \pm \text { SEM }\end{array}$ & $\begin{array}{c}10 \% \text { FBS }+ \text { CCCP } \\
\text { Mean } \pm \text { SEM }\end{array}$ & $\begin{array}{c}\text { SS } \\
\text { Mean } \pm \text { SEM }\end{array}$ \\
\hline H20 & $58 \mathrm{kDa}$ & $0.08 \pm 0.01$ & $0.11 \pm 0.01$ & $0.31 \pm 0.03 *$ & $0.26 \pm 0.06$ \\
\hline HI/HS & $50 \mathrm{kDa}$ & $5.68 \pm 0.12$ & $8.56 \pm 0.02 * * *$ & $10.73 \pm 0.03 * *$ & $6.72 \pm 0.03 * *$ \\
\hline
\end{tabular}

Figure 4. Expression profile of parkin isoforms in glioblastoma cell lines detected by the AbII antibody. Representative immunoblot of lysate from T98G (A), A172 (B) and U87MG (C) cells immunoprecipitated with AbII antibody. Cells were cultured in 10\% FBS or 10\% FBS with MG132 or 10\% FBS with CCCP or without serum (SS). Relative density of each band was quantified using ImageJ software. Each signal was normalized on correspondent $\beta$-tubulin signal. Data are expressed as mean \pm SEM. ${ }^{*}$ p $<0.05$ vs. $10 \%$ FBS, ${ }^{* *}$ p $<0.01$ vs. $10 \%$ FBS, ${ }^{* * *}$ p $<0.001$ vs. $10 \%$ FBS as determined by one-way ANOVA followed by the Tukey post hoc test. 


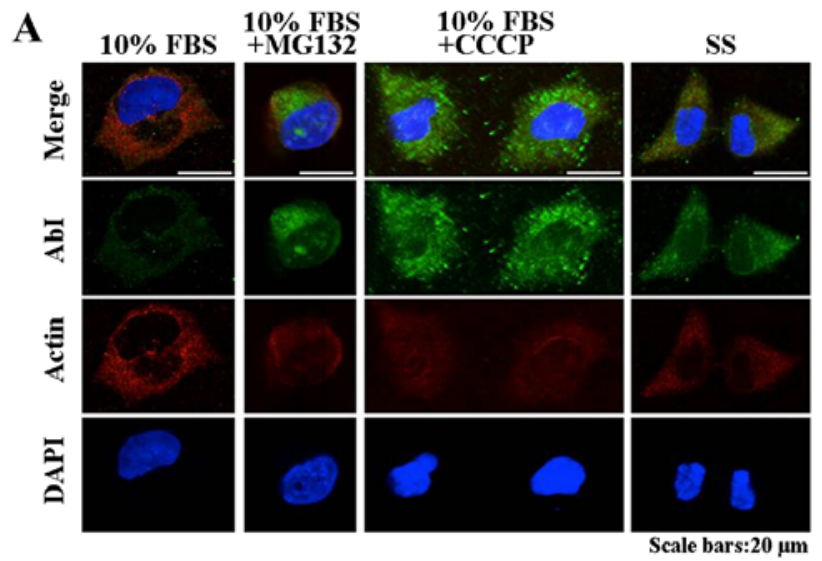

\begin{tabular}{|c|c|c|c|}
\hline \multicolumn{4}{|c|}{ TOTAL ISOFORMS EXPRESSION } \\
\hline $10 \%$ FBS & $\begin{array}{c}10 \% \text { FBS }+ \\
\text { MG132 }\end{array}$ & $\mathbf{1 0 \% \text { FBS } + \text { CCCP }}$ & SS \\
\hline 0.99 & 2.1 & 3.48 & 4.19 \\
\hline
\end{tabular}
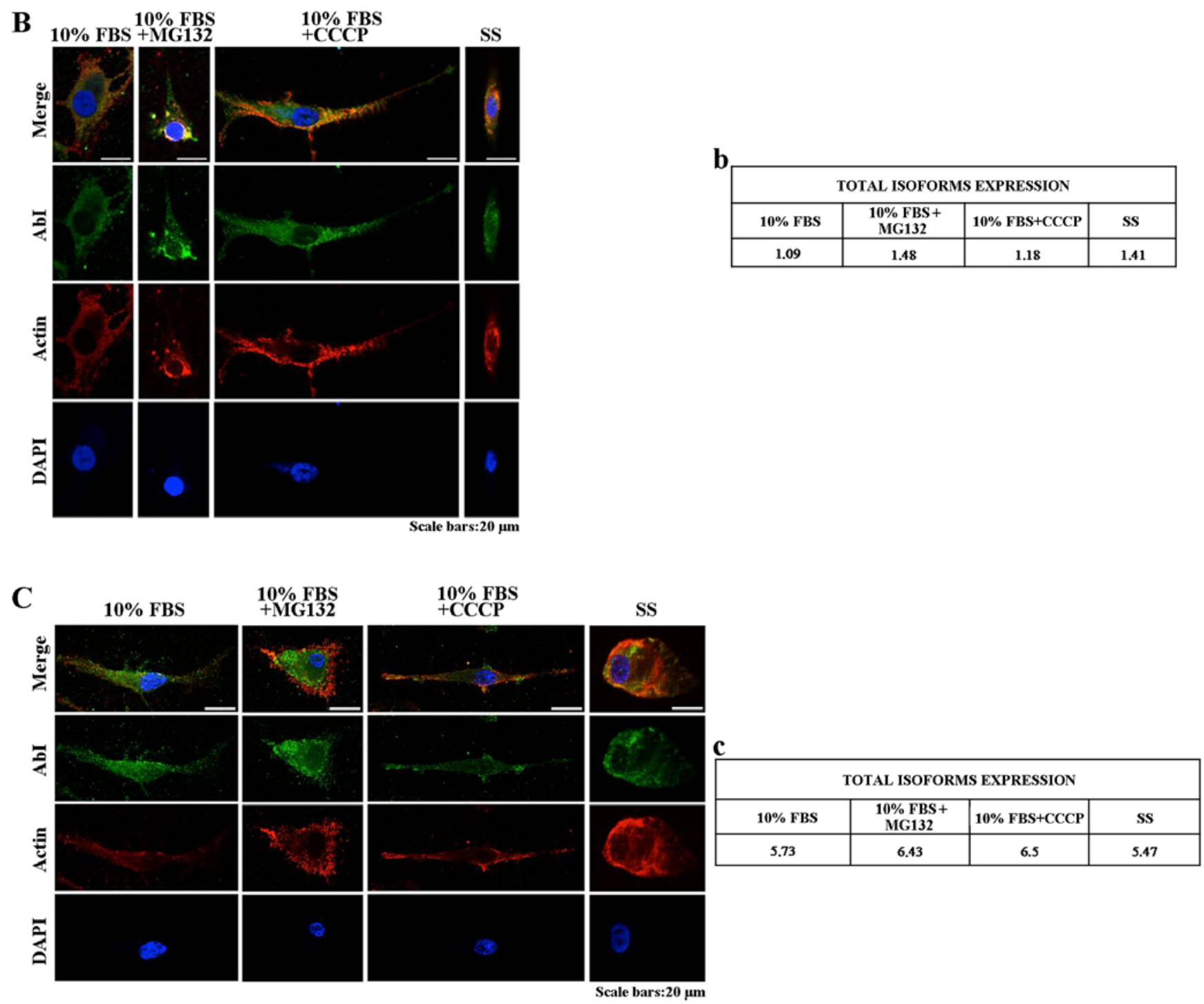

Figure 5. Immunolocalization of total parkin isoforms in glioblastoma cell lines detected by the AbI antibody. Representative photomicrographs showing total parkin isoforms (green) detected by AbI antibody in T98G (A), A172 (B) and U87MG (C) cells. $\beta$-actin (red) was used as control and nuclei were stained with DAPI (blue). Cells were cultured in 10\% FBS or 10\% FBS with MG132 or 10\% FBS with CCCP or without serum (SS). Photomicrographs are representative results of fields taken randomly from slide and scanned by Zeiss fluorescent microscope. Each table (a-c) lists the total expression levels of parkin isoforms in every experimental condition by summing mean values reported in tables of Fig. 3A-C.

molecular weight was revealed on blot by both antibodies (Fig. 1A-E). This discrepant data might be due to manipulations performed on paraffin-embedded samples which induce some structural alterations in antigenic site of these isoforms modifying the domain recognized by the antibody. A previous study described the main aspects resulting from different 

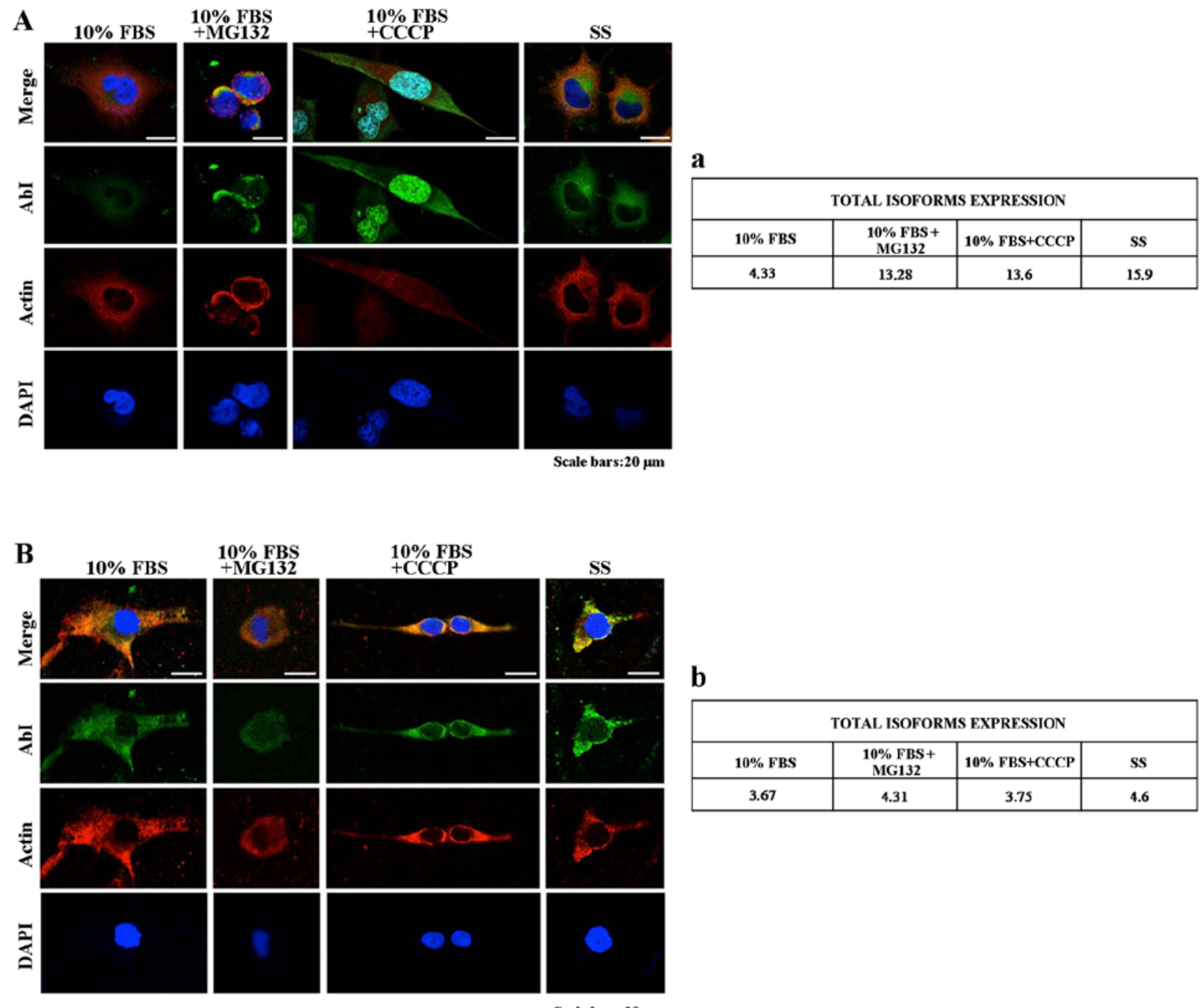

b
\begin{tabular}{|c|c|c|c|}
\hline \multicolumn{4}{|c|}{ TOTAL ISOFORMS EXPRESSION } \\
\hline $\mathbf{1 0} \%$ FBS & $\begin{array}{c}\mathbf{1 0} \% \text { F FS+ } \\
\text { MG132 }\end{array}$ & $\mathbf{1 0} \%$ FBS+CCCP & SS \\
\hline 3.67 & 4.31 & 3.75 & 4.6 \\
\hline
\end{tabular}

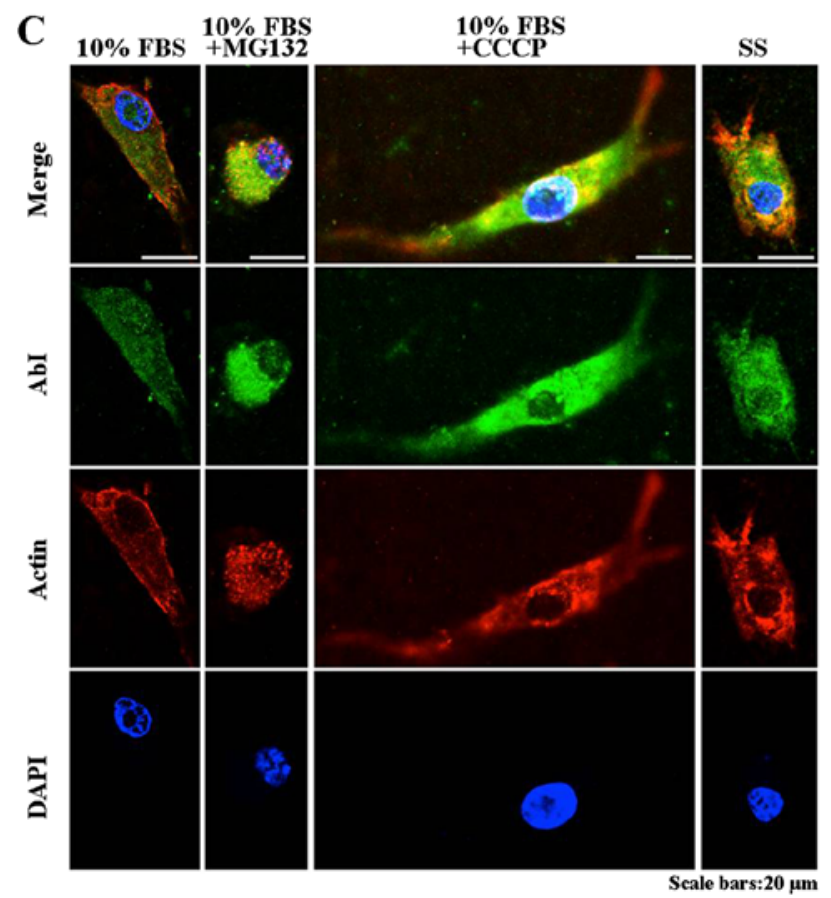

\begin{tabular}{|c|c|c|c|}
\hline \multicolumn{4}{|c|}{ TOTAL ISOFORMS EXPRESSION } \\
\hline $10 \%$ FBS & $\begin{array}{c}10 \% \text { FBS }+ \\
\text { MG132 }\end{array}$ & $10 \%$ FBS+CCCP & Ss \\
\hline 5.76 & 8.67 & 11.04 & 6.98 \\
\hline
\end{tabular}

Figure 6. Immunolocalization of parkin isoforms in glioblastoma cell lines detected by the AbII antibody. Representative photomicrographs showing total parkin isoforms (green) detected by AbII antibody in T98G (A), A172 (B) and U87MG (C) cells. $\beta$-actin (red) was used as control and nuclei were stained with DAPI (blue). Cells were cultured in 10\% FBS or 10\% FBS with MG132 or 10\% FBS with CCCP or without serum (SS). Photomicrographs are representative results of fields taken randomly from slide and scanned by Zeiss fluorescent microscope. Each table (a-c) lists the total expression levels of parkin isoforms in every experimental condition by summing mean values reported in tables of Fig. 4A-C. 
processing of the samples (47). In particular the authors suggested that proteins denaturation in frozen is less intense than in paraffin-embedded samples, because they are not exposed to organic solvents and heat.

Previously, we also investigated whether parkin isoforms expressed in glioma perform different functions. Originally, it was demonstrated that parkin acts as an E3 ubiquitin-ligase by targeting protein as substrate for proteasomal degradation (5). The loss of parkin function, as observed in some forms of Parkinsonism, leads to the accumulation of toxic substrates damaging dopaminergic neurons and consequently causing the disease. However, during recent years a wide range of other activities has been described. The parkin function seems not limited to the degradative ubiquitination of single substrates, but might also include the regulation of some fundamental cellular processes (10).

It has been demonstrated that it prevents apoptotic cell death and stimulates mitochondrial biogenesis to eliminate severely damaged mitochondria via mitophagy $(12,48)$. Furthermore, more recently, a further role of parkin has been suggested as a transcriptional repressor of p53 which is also involved in the process of programmed cell death $(13,14,49)$. To characterize the involvement of these isoforms in some of the cellular processes, their expression in three glioblastoma cell lines was analyzed after treatment with a proteasome inhibitor MG132, or induction of autophagy with CCCP or serum deprivation. To visualize specific signals on the blot, parkin proteins have been immunoprecipitated from cell lysate by using AbI or AbII antibody. In samples from tissue sections, it was not possible to perform this method because the protein yield was very low. Basal expression levels of isoforms, as well as after treatments, are correlated to each cellular phenotype. Nonetheless, it has been observed that some isoforms, such as $\mathrm{H} 20, \mathrm{H} 1$ and $\mathrm{H} 5$, are always expressed both in vivo and in vitro tumors.

Our results suggest that these isoforms might be specific markers of malignancy and they might be used in a diagnostic tool for brain tumors. To better characterize their role, it is also desirable that new antibodies, selectively identifying these isoforms, will be produced. Finally, further studies by using more sophisticated technologies are needed to identify and functionally characterize each isoform.

\section{Acknowledgements}

This study was supported by the International $\mathrm{PhD}$ Program in Neuroscience, University of Catania. We also gratefully acknowledge Cristina Calì, Alfia Corsino, Maria Patrizia D'Angelo and Francesco Marino for their administrative and technical support.

\section{References}

1. Kitada T, Asakawa S, Hattori N, Matsumine H, Yamamura $Y$, Minoshima S, Yokochi M, Mizuno Y and Shimizu N: Mutations in the parkin gene cause autosomal recessive juvenile parkinsonism. Nature 392: 605-608, 1998.

2. La Cognata V, Iemmolo R, D'Agata V, Scuderi S, Drago F, Zappia M and Cavallaro S: Increasing the coding potential of genomes through alternative splicing: The case of PARK2 gene. Curr Genomics 15: 203-216, 2014

3. Walden H and Martinez-Torres RJ: Regulation of Parkin E3 ubiquitin ligase activity. Cell Mol Life Sci 69: 3053-3067, 2012.
4. Hristova VA, Beasley SA, Rylett RJ and Shaw GS: Identification of a novel $\mathrm{Zn}^{2+}$-binding domain in the autosomal recessive juvenile Parkinson-related E3 ligase parkin. J Biol Chem 284: 14978-14986, 2009.

5. Shimura H, Hattori N, Kubo S, Mizuno Y, Asakawa S, Minoshima S, Shimizu N, Iwai K, Chiba T, Tanaka K, et al: Familial Parkinson disease gene product, parkin, is a ubiquitinprotein ligase. Nat Genet 25: 302-305, 2000.

6. Ledesma MD, Galvan C, Hellias B, Dotti C and Jensen PH: Astrocytic but not neuronal increased expression and redistribution of parkin during unfolded protein stress. J Neurochem 83: 1431-1440, 2002

7. Kitada T, Asakawa S, Minoshima S, Mizuno Y and Shimizu N: Molecular cloning, gene expression, and identification of a splicing variant of the mouse parkin gene. Mamm Genome 11: 417-421, 2000.

8. Solano SM, Miller DW, Augood SJ, Young AB and Penney JB Jr: Expression of alpha-synuclein, parkin, and ubiquitin carboxyterminal hydrolase L1 mRNA in human brain: Genes associated with familial Parkinson's disease. Ann Neurol 47: 201-210, 2000.

9. Fett ME, Pilsl A, Paquet D, van Bebber F, Haass C, Tatzelt J, Schmid B and Winklhofer KF: Parkin is protective against proteotoxic stress in a transgenic zebrafish model. PLoS One 5: e11783, 2010.

10. Trempe JF and Fon EA: Structure and function of Parkin, PINK1, and DJ-1, the three musketeers of neuroprotection. Front Neurol 4: 38,2013

11. Henn IH, Bouman L, Schlehe JS, Schlierf A, Schramm JE, Wegener E, Nakaso K, Culmsee C, Berninger B, Krappmann D, et al: Parkin mediates neuroprotection through activation of IkappaB kinase/nuclear factor-kappaB signaling. J Neurosci 27: 1868-1878, 2007.

12. Winklhofer KF: Parkin and mitochondrial quality control: Toward assembling the puzzle. Trends Cell Biol 24: 332-341, 2014.

13. da Costa CA, Sunyach C, Giaime E, West A, Corti O, Brice A, Safe S, Abou-Sleiman PM, Wood NW, Takahashi H, et al: Transcriptional repression of p53 by parkin and impairment by mutations associated with autosomal recessive juvenile Parkinson's disease. Nat Cell Biol 11: 1370-1375, 2009.

14. Sunico CR, Nakamura T, Rockenstein E, Mante M, Adame A, Chan SF, Newmeyer TF, Masliah E, Nakanishi N and Lipton SA: S-Nitrosylation of parkin as a novel regulator of p53-mediated neuronal cell death in sporadic Parkinson's disease. Mol Neurodegener 8: 29, 2013.

15. Quinn N, Critchley P and Marsden CD: Young onset Parkinson's disease. Mov Disord 2: 73-91, 1987.

16. Takahashi H, Ohama E, Suzuki S, Horikawa Y, Ishikawa A, Morita T, Tsuji S and Ikuta F: Familial juvenile parkinsonism: Clinical and pathologic study in a family. Neurology 44: 437-441, 1994.

17. Golbe LI: Young-onset Parkinson's disease: A clinical review. Neurology 41: 168-173, 1991.

18. Cesari R, Martin ES, Calin GA, Pentimalli F, Bichi R, McAdams H, Trapasso F, Drusco A, Shimizu M, Masciullo V, et al: Parkin, a gene implicated in autosomal recessive juvenile parkinsonism, is a candidate tumor suppressor gene on chromosome 6q25-q27. Proc Natl Acad Sci USA 100: 5956-5961, 2003.

19. Denison SR, Wang F, Becker NA, Schüle B, Kock N, Phillips LA, Klein $\mathrm{C}$ and Smith DI: Alterations in the common fragile site gene Parkin in ovarian and other cancers. Oncogene 22: 8370-8378, 2003.

20. Picchio MC, Martin ES, Cesari R, Calin GA, Yendamuri S, Kuroki T, Pentimalli F, Sarti M, Yoder K, Kaiser LR, et al: Alterations of the tumor suppressor gene Parkin in non-small cell lung cancer. Clin Cancer Res 10: 2720-2724, 2004.

21. Wang F, Denison S, Lai JP, Philips LA, Montoya D, Kock N, Schüle B, Klein C, Shridhar V, Roberts LR, et al: Parkin gene alterations in hepatocellular carcinoma. Genes Chromosomes Cancer 40: 85-96, 2004

22. Yeo CWS, Ng FSL, Chai C, Tan JM, Koh GR, Chong YK, Koh LW, Foong CS, Sandanaraj E, Holbrook JD, et al: Parkin pathway activation mitigates glioma cell proliferation and predicts patient survival. Cancer Res 72: 2543-2553, 2012.

23. Ohgaki $\mathrm{H}$ and Kleihues P: The definition of primary and secondary glioblastoma. Clin Cancer Res 19: 764-772, 2013.

24. Rong Y,Durden DL, Van Meir EG and Brat DJ: 'Pseudopalisading' necrosis in glioblastoma: A familiar morphologic feature that links vascular pathology, hypoxia, and angiogenesis. J Neuropathol Exp Neurol 65: 529-539, 2006. 
25. Svensson KJ, Kucharzewska P, Christianson HC, Sköld S Löfstedt T, Johansson MC, Mörgelin M, Bengzon J, Ruf W and Belting M: Hypoxia triggers a proangiogenic pathway involving cancer cell microvesicles and PAR-2-mediated heparin-binding EGF signaling in endothelial cells. Proc Natl Acad Sci USA 108: 13147-13152, 2011

26. Veeriah S, Taylor BS, Meng S, Fang F, Yilmaz E, Vivanco I, Janakiraman M, Schultz N, Hanrahan AJ, Pao W, et al: Somatic mutations of the Parkinson's disease-associated gene PARK2 in glioblastoma and other human malignancies. Nat Genet 42 : 77-82, 2010

27. Xu L, Lin DC, Yin D and Koeffler HP: An emerging role of PARK2 in cancer. J Mol Med Berl 92: 31-42, 2014.

28. Stamm S, Ben-Ari S, Rafalska I, Tang Y, Zhang Z, Toiber D, Thanaraj TA and Soreq H: Function of alternative splicing. Gene 344: 1-20, 2005 .

29. Shin C and Manley JL: Cell signalling and the control of pre-mRNA splicing. Nat Rev Mol Cell Biol 5: 727-738, 2004

30. Modrek B and Lee C: A genomic view of alternative splicing. Nat Genet 30: 13-19, 2002.

31. Scuderi S, La Cognata V, Drago F, Cavallaro S and D'Agata V: Alternative splicing generates different parkin protein isoforms: Evidences in human, rat, and mouse brain. BioMed Res Int 2014 690796, 2014.

32. Sunada Y, Saito F, Matsumura K and Shimizu T: Differential expression of the parkin gene in the human brain and peripheral leukocytes. Neurosci Lett 254: 180-182, 1998.

33. Dagata V and Cavallaro S: Parkin transcript variants in rat and human brain. Neurochem Res 29: 1715-1724, 2004.

34. Beyer K, Domingo-Sàbat M, Humbert J, Carrato C, Ferrer I and Ariza A: Differential expression of alpha-synuclein, parkin, and synphilin-1 isoforms in Lewy body disease. Neurogenetics 9: $163-172,2008$.

35. Humbert J, Beyer K, Carrato C, Mate JL, Ferrer I and Ariza A: Parkin and synphilin-1 isoform expression changes in Lewy body diseases. Neurobiol Dis 26: 681-687, 2007.

36. Tan EK, Shen H, Tan JM, Lim KL, Fook-Chong S, Hu WP, Paterson MC, Chandran VR, Yew K, Tan C, et al: Differential expression of splice variant and wild-type parkin in sporadic Parkinson's disease. Neurogenetics 6: 179-184, 2005.

37. Bouman L, Schlierf A, Lutz AK, Shan J, Deinlein A, Kast J, Galehdar Z, Palmisano V, Patenge N, Berg D, et al: Parkin is transcriptionally regulated by ATF4: Evidence for an interconnection between mitochondrial stress and ER stress. Cell Death Differ 18: 769-782, 2011.
38. Narendra D, Tanaka A, Suen DF and Youle RJ: Parkin is recruited selectively to impaired mitochondria and promotes their autophagy. J Cell Biol 183: 795-803, 2008.

39. Ikeuchi K, Marusawa H, Fujiwara M, Matsumoto Y, Endo Y, Watanabe T, Iwai A, Sakai Y, Takahashi R and Chiba T: Attenuation of proteolysis-mediated cyclin $\mathrm{E}$ regulation by alternatively spliced Parkin in human colorectal cancers. Int J Cancer 125: 2029-2035, 2009.

40. Klinkenberg M, Gispert S, Dominguez-Bautista JA, Braun I, Auburger $\mathrm{G}$ and Jendrach M: Restriction of trophic factors and nutrients induces PARKIN expression. Neurogenetics 13: 9-21, 2012.

41. Huynh DP, Scoles DR, Ho TH, Del Bigio MR and Pulst SM Parkin is associated with actin filaments in neuronal and nonneural cells. Ann Neurol 48: 737-744, 2000.

42. D'Agata V, Grimaldi M, Pascale A and Cavallaro S: Regional and cellular expression of the parkin gene in the rat cerebral cortex. Eur J Neurosci 12: 3583-3588, 2000.

43. D'Agata V, Zhao W, Pascale A, Zohar O, Scapagnini G and Cavallaro S: Distribution of parkin in the adult rat brain. Prog Neuropsychopharmacol Biol Psychiatry 26: 519-527, 2002.

44. Cookson MR, Lockhart PJ, McLendon C, O'Farrell C, Schlossmacher $\mathrm{M}$ and Farrer MJ: RING finger 1 mutations in Parkin produce altered localization of the protein. Hum Mol Genet 12: 2957-2965, 2003

45. Hampe C, Ardila-Osorio H, Fournier M, Brice A and Corti O: Biochemical analysis of Parkinson's disease-causing variants of Parkin, an E3 ubiquitin-protein ligase with monoubiquitylation capacity. Hum Mol Genet 15: 2059-2075, 2006.

46. Sriram SR, Li X, Ko HS, Chung KK, Wong E, Lim KL, Dawson VL and Dawson TM: Familial-associated mutations differentially disrupt the solubility, localization, binding and ubiquitination properties of parkin. Hum Mol Genet 14: 2571-2586, 2005.

47. Yamashita S and Okada Y: Application of heat-induced antigen retrieval to aldehyde-fixed fresh frozen sections. J Histochem Cytochem 53: 1421-1432, 2005.

48. Müller-Rischart AK, Pilsl A, Beaudette P, Patra M, Hadian K, Funke M, Peis R, Deinlein A, Schweimer C, Kuhn PH, et al: The E3 ligase parkin maintains mitochondrial integrity by increasing linear ubiquitination of NEMO. Mol Cell 49: 908-921, 2013.

49. Alves da Costa C and Checler F: Apoptosis in Parkinson's disease: Is p53 the missing link between genetic and sporadic Parkinsonism? Cell Signal 23: 963-968, 2011. 